\title{
Indeterminate Pronouns: The View from Japanese*
}

Paper presented at the 3rd Tokyo Conference on Psycholinguistics

March 2002

\author{
Angelika Kratzer \\ UNIVERSITY OF MASSACHUSETTS \\ AMHERST
}

\author{
Junko Shimoyama \\ KYUSHU INSTITUTE OF \\ TECHNOLOGY
}

\section{Cross-linguistic Variation}

The traditional view on natural language quantification is that languages have determiner quantifiers projecting DPs that scope overtly or covertly, subject to the usual constraints on movement. The quantification system in Japanese does not seem to conform to this picture. In Japanese, quantifier phrases are built using what scholars of Japanese commonly refer to as 'indeterminate pronouns' (Kuroda 1965):

(1)

$$
\begin{aligned}
& \text { dare 'who' } \\
& \text { nani 'what' } \\
& \text { dore 'which (one)' } \\
& \text { dono 'which' (Det) }
\end{aligned}
$$

$$
\begin{aligned}
& \text { doko 'where' } \\
& \text { itu 'when' } \\
& \text { naze 'why' } \\
& \text { doo 'how' }
\end{aligned}
$$

\footnotetext{
A slightly shorter version of this paper appears in Yukio Otsu (ed.): The Proceedings of the Third Tokyo Conference on Psycholinguistics. Tokyo (Hituzi Syobo), 2002, 1-25. We would like to thank the audiences at the 13th Amsterdam Colloquium, the Third Tokyo Conference on Psycholinguistics, UCLA, UMass Amherst, and in particular Bernhard Schwarz for helpful comments.
}

$*$ 
Depending on the operator they 'associate with', Japanese indeterminate phrases can take on existential, universal, interrogative, negative polarity, or free choice interpretations. 2(a) is an example of the universal construction, and 2(b) is an example of a wh-question.

a. [[Dono hon-o yonda $]$ kodomo] -mo yoku nemutta. which book-ACC read child -MO well slept 'For every book $\mathrm{x}$, the child who read x slept well.'

b. Taro-wa [[dare-ga katta] mochi]-o tabemasita ka? Taro-TOP who-NOM bought rice cake-ACC ate Q 'Who is the $\mathrm{x}$ such that Taro ate rice cakes that $\mathrm{x}$ bought?'

A first connection between quantification in Japanese and in English was established by Nishigauchi 1986, 1990. Nishigauchi argued that some Japanese quantifiers are adverbial quantifiers, and that they can unselectively bind variables made available by indeterminate phrases and bare NPs, as proposed in Heim 1982. The semantic part of Nishigauchi's analysis was criticized by Ohno 1989 and von Stechow 1996. Von Stechow 1996 also attempted to provide an explicit analysis of the syntax-semantics mapping. However, his analysis relies on assumptions for Japanese that are idiosyncratic and ad hoc (see Shimoyama 2001), hence moves us away from a possible explanation for how apparently different types of quantifiers can be acquired by children.

In his typological survey of indefinite pronouns Haspelmath 1997 shows that indeterminate pronouns in the Japanese sense constitute a unified class crosslinguistically. An example is Latvian (Haspelmath 1997, p. 277, diacritics omitted): 


\begin{tabular}{|l|l|l|l|l|}
\hline & Interrogative & kaut-series & ne-series & jeb-series \\
\hline person & kas & kaut kas, kads & ne-viens & jeb-kads \\
\hline thing & kas & kaut kas & ne-kas & jeb-kas \\
\hline place & kur & kaut kur & ne-kur & jeb-kur \\
\hline time & kad & kaut kad & ne-kad & jeb-kad \\
\hline manner & ka & kaut ka & ne-ka & \\
\hline determiner & kads, kurs & kaut kads & ne-kads & $\begin{array}{l}\text { jeb-kads, } \\
\text { jeb-kurs }\end{array}$ \\
\hline
\end{tabular}

The Latvian 'bare' series has interrogatives. The kaut- series has existentials. The ne-series appears under the direct scope of negation, and the jeb-series is found in indirect negation contexts, in comparatives, and also with a free choice interpretation. If indeterminate phrases form a natural class cross-linguistically, the question arises as to what it is that makes Japanese quantifier and interrogative constructions look so different from their counterparts in Indo-European languages. In this paper, we will take a first step towards answering this question by presenting an analysis of the German indeterminate pronoun/determiner irgendein from a Japanese point of view. We will show that the Japanese perspective allows us to explain some puzzling properties of irgendein and free choice indefinites more generally. We will also address the differences between Indo-European and Japanese indeterminate pronouns and speculate that they might ultimately reduce to the presence or absence of uninterpretable features that give Indo-European indeterminate pronouns their selective look.

\section{A Hamblin Semantics for Indeterminate Pronouns in Japanese}

Hamblin originally designed his alternative semantics for run-of-the mill questions in English. As far as we are aware, the first extension to quantification in languages other than English is Ramchand 1997. Hagstrom 1998 applied Hamblin's semantics to existentially quantified sentences in Japanese. 
Shimoyama $(1999,2001)$ established the connection with universally quantified sentences, and argued moreover for an in situ interpretation of indeterminate phrases. The guiding idea behind a Hamblin semantics for indeterminate phrases is that they introduce sets of alternatives that keep 'expanding' until they meet an operator that selects them. The alternatives can be of different semantic types, such as individuals, properties and propositions, and consequently, we expect the existence of quantifiers that can operate over alternatives of different semantic types. Determiner quantification falls out as a special case, the case where the alternatives are individuals. ${ }^{1}$ On such an analysis, the Japanese universal quantifier mo can be analyzed as a regular generalized quantifier, and the semantics of sentence 2(a), for example, can be sketched as in (3).

(3) All members of A slept well: $\mathrm{A}=$ \{the child who read book a, the child who read book b, the child who read book $c, \ldots .$.

A second important consequence of a Hamblin analysis for indeterminate phrases in Japanese is that while allowing for long-distance association between indeterminate phrases and particles as in (2), it automatically derives the locality conditions for this association without any stipulations. Indeterminate phrases in Japanese must associate with the closest available operator:

1 Thanks to Akira Watanabe for bringing to our attention the fact that Japanese lacks a quantificational particle meaning most that takes indeterminate phrases. Here is how 'most' is expressed in Japanese (the 'floated' versions are also possible). $\mathrm{NO}=$ pre-nominal modification marker.

$$
\begin{array}{lll}
\text { Hotondo-no } & \text { gakusei-ga } & \text { utatta. } \\
\text { most-NO } & \text { student-NOM } & \text { sang } \\
\text { 'Most students sang.' } &
\end{array}
$$

Watanabe pointed out that the question of whether the above fact is an accident in Japanese, or it holds across languages that has Japanese-type systematic indeterminate phrase quantification, should have consequences in the validity of the claim that determiner quantification is reduced to a special case. 
* $\quad[\ldots . .[\ldots$ ind $\ldots . . \mathrm{ka} / \mathbf{m o}] \ldots . .]-.\mathbf{k a} / \mathbf{m o}$

On a Hamblin analysis, the alternatives created by an indeterminate phrase can expand across relative clause boundaries as illustrated in (2). They are, however, caught by the first relevant operator in their way. In (4), which illustrates a typical intervention effect, the alternatives created by the indeterminate pronoun must associate with the lower $\mathbf{k a / m o}$. It could not be otherwise. The intervention effects follow from the very architecture of the interpretation system, in interaction with structural configurations. No locality principles have to be stated in the grammar.

Here is a brief illustration of how the interpretation of the simple sentence Dare(ga) nemutta is computed in a Hamblin semantics. We give an overview of the essential definitions of the interpretation system in the Appendix of section 3, which can be skipped by readers who are not interested in the technical parts of our proposal. In a Hamblin semantics, all expressions denote sets of 'traditional' denotations. These are the alternatives. Most lexical items denote singleton sets. The main innovation comes with indeterminate pronouns and phrases. Those denote sets of individuals. We have to think of those sets as individual alternatives, rather than as properties. This is the major conceptual shift in Hamblin's system. Via pointwise functional application, the alternatives created by indeterminate phrases can 'expand'. More formally, we have (for all possible worlds $\mathrm{w}$ and variable assignments g): 
$\begin{array}{ll}{[[\text { dare }]]^{\mathrm{w}, \mathrm{g}}} & =\{\mathrm{x}: \operatorname{human}(\mathrm{x})(\mathrm{w})\} \\ {[[\text { nemutta }]]^{\mathrm{w}, \mathrm{g}}} & =\left\{\square \mathrm{x} \square \mathrm{w}^{\prime} \cdot \operatorname{slept}(\mathrm{x})\left(\mathrm{w}^{\prime}\right)\right\} \\ {[[\text { dare nemutta }]]^{\mathrm{w}, \mathrm{g}}} & =\left\{\mathrm{p}: \square \mathrm{x}\left[\operatorname{human}(\mathrm{x})(\mathrm{w}) \& \mathrm{p}=\square \mathrm{w}^{\prime} \cdot \operatorname{slept}(\mathrm{x})\left(\mathrm{w}^{\prime}\right)\right]\right\}\end{array}$

Dare ('who') denotes the set of all humans. The verb nemutta ('slept') denotes a singleton set - it introduces just one alternative, a property. The denotation of the sentence Dare(-ga) nemutta is a set of propositions of the form ['a slept', 'b slept', 'c slept', etc.\}. To compute this set, we apply functional application 'pointwise'. The alternatives can expand until they meet an operator that selects them. Here is an overview of the most common operators. The propositional ones operate over propositional alternatives, the generalized quantifiers operate over individual alternatives.

\section{Propositional quantifiers}

Where $\mathrm{A}$ is a set of propositions, we have:

[D](A) = $\quad$ the proposition that is true in all worlds in which some proposition in $\mathrm{A}$ is true\}

$[\square](\mathrm{A})=$ the proposition that is true in all worlds in which every proposition in $\mathrm{A}$ is true\}

[Neg] $(\mathrm{A})=$ the proposition that is true in all worlds in which no proposition in $\mathrm{A}$ is true

$[\mathrm{Q}](\mathrm{A})=\mathrm{A}$ (or other denotations, see Appendix) 


\section{Generalized quantifiers}

Where $\mathrm{A}$ is a set of individuals, we have:

$[\square](\mathrm{A})=$ the property of properties that is true of any property if some individual in A has it. $\}$

[D] (A) = $\quad$ the property of properties that is true of any property if every individual in A has it. $\}$

And so on, for the others.

\section{Appendix: The semantic interpretation system}

This appendix gives an outline of the components of a Hamblin semantics, listing the major composition principles. In line with much recent work on the topic, we assume that composition principles are largely type-driven, and apply freely whenever they can.

\section{Hamblin Functional Application}

If $\square$ is a branching node with daughters $\square$ and $\square$ and $[[\square]]^{\mathrm{w}, \mathrm{g}} \square \mathrm{D}_{\square}$ and $[[\square]]^{\mathrm{w}, \mathrm{g}} \square \mathrm{D}_{<\square[\mathrm{g}}$, then $[[\square]]^{\mathrm{w}, \mathrm{g}}=\left\{\mathrm{a} \square \mathrm{D}_{\square}: \square \mathrm{b} \square \mathrm{c}\left[\mathrm{b} \square[[\square]]^{\mathrm{w}, \mathrm{g}} \& \mathrm{c} \square[[\square]]^{\mathrm{w}, \mathrm{g}} \& \mathrm{a}=\right.\right.$ c(b)] \}.

$\underline{\text { Sentential quantifiers }}^{2}$

For $[[\square]]^{\mathrm{w}, \mathrm{g}} \square \mathrm{D}_{<\mathrm{st}>}$ :

(i) $[[\square \square]]^{\mathrm{w}, \mathrm{g}}=\left\{\square \mathrm{w}^{\prime}\right.$. $\left.\square \mathrm{p}\left[\mathrm{p} \square[[\square]]^{\mathrm{w}, \mathrm{g}} \& \mathrm{p}\left(\mathrm{w}^{\prime}\right)=1\right]\right\}$

(ii) $[[\square \square]]^{\mathrm{w}, \mathrm{g}}=\left\{\square \mathrm{w}^{\prime} \cdot \square \mathrm{p}\left[\mathrm{p} \square[[\square]]^{\mathrm{w}, \mathrm{g}} \square \mathrm{p}\left(\mathrm{w}^{\prime}\right)=1\right]\right\}$

2. There should be a choice for the world index with respect to which $\square$ is to be evaluated in (i) to (iv), an issue we will neglect here and below. 
(iii)

$[[\operatorname{Neg} \square]]^{\mathrm{w}, \mathrm{g}}=\left\{\square \mathrm{w}^{\prime} \cdot \square \square \mathrm{p}\left[\mathrm{p} \square[[\square]]^{\mathrm{w}, \mathrm{g}} \& \mathrm{p}\left(\mathrm{w}^{\prime}\right)=1\right]\right\}$

(iv) $[[\mathrm{Q} \square]]^{\mathrm{w}, \mathrm{g}}=[[\square]]^{\mathrm{w}, \mathrm{g}}$ or (Groenendijk \& Stokhof 1984)

$$
[[\mathrm{Q} \square]]^{\mathrm{w}, \mathrm{g}}=\left\{\square \mathrm{w}^{\prime} \cdot \square \mathrm{p}\left[\mathrm{p} \square[[\square]]^{\mathrm{w}, \mathrm{g}} \square\left[\mathrm{p}(\mathrm{w})=1 \square \mathrm{p}\left(\mathrm{w}^{\prime}\right)=1\right]\right]\right\}
$$

\section{Generalized quantifiers}

For $[[\square]]^{\mathrm{w}, \mathrm{g}} \square \mathrm{D}_{\mathrm{e}}$ :

(i) $\quad[[\square \square]]^{\mathrm{w}, \mathrm{g}}=\left\{\square \mathrm{P} \square \mathrm{w}^{\prime}\right.$. $\left.\square \mathrm{a}\left[\mathrm{a} \square[[\square]]^{\mathrm{w}, \mathrm{g}} \& \mathrm{P}(\mathrm{a})\left(\mathrm{w}^{\prime}\right)=1\right]\right\}$

(ii) $[[\square \square]]^{w, g}=\left\{\square \mathrm{P} \square w^{\prime} \cdot \square \mathrm{a}\left[\mathrm{a} \square[[\square]]^{\mathrm{w}, \mathrm{g}} \square \mathrm{P}(\mathrm{a})\left(\mathrm{w}^{\prime}\right)=1\right]\right\}$

Etc.

\section{Predicate Abstraction}

If $\square$ is a branching node whose daughters are an index $\mathrm{i}$ and $\square$, where $[[\square]]^{\mathrm{w}, \mathrm{g}} \square \mathrm{D}_{\square}$, then $[[\square]]^{\mathrm{w}, \mathrm{g}}=\left\{\mathrm{f}: \mathrm{f} \square \mathrm{D}_{<\mathrm{e} \square>} \& \square \mathrm{a}\left[\mathrm{f}(\mathrm{a}) \square[[\square]]^{\mathrm{w}, \mathrm{g}[\mathrm{a} / \mathrm{i}]}\right]\right\}^{3}$.

Pronouns and traces

For any index $\mathrm{i},[[\mathrm{i}]]^{\mathrm{w}, \mathrm{g}}=\{\mathrm{g}(\mathrm{i})\}$.

\section{A Japanese analysis of German irgendein}

In the first part of our paper, we introduced a theory of quantification where determiner quantifiers and propositional quantifiers fall out as special cases. Such a theory captures three distinctive properties of Japanese indeterminate phrases: their interpretational variability, apparent locality violations, and the intervention effects. In what follows, we present a case study of a single indefinite: German

3 There is a question about the correctness of the definition for Predicate Abstraction. It does not quite deliver the expected set of functions. As far as we can see, however, no wrong predictions are actually made, as long as we only use the definition for generating propositional alternatives. 
irgendein. Next to a Japanese indeterminate phrase, irgendein looks like a rather dull existential that is unlikely to contribute any new insights into the properties of quantification. It doesn't show any quantificational variability at all. Moreover, it doesn't seem to have exceptional scope properties. When we look closer, however, we discover that irgendein has other properties that consistently show up with quantifiers in the languages of the world: It triggers free choice effects in the scope of modals and displays what we might describe as 'polarity sensitivity'. We will show that a Hamblin semantics for irgendein explains why it can have those properties in addition to its quantificational and scope characteristics. Moreover, by arguing for a Hamblin semantics for both irgendein and indeterminate pronouns in Japanese, we hope to motivate a unified theory of quantification that has the right architecture to account for the core properties of quantifiers, including categorial variability (e.g. determiners vs. sentential operators), interpretational variability (e.g. interrogative, existential, universal), scope properties, polarity sensitivity, free choice effects, and intervention effects.

The typical properties of irgendein are illustrated in (5) to (7). In (6), we see a subtle epistemic effect. By using irgendein, Hans conveys that he doesn't know or care about who called, or thinks the identity of the speaker is irrelevant. Maria's question is pragmatically inappropriate, then. Choosing irgendein in (7), Maria expresses indifference as to the choice of guests. Anybody in the universe of discourse would be fine with her. Jemand would be pragmatically inappropriate. The simple indefinite, would merely repeat what the question already presupposes. 
Epistemic effects $^{4}$

(5) Hans: Jemand hat angerufen.

Somebody has called.

Maria: Wer war es?

Who was it

(6) Hans: Irgendjemand hat angerufen. Ignorance

Irgend-one has called

Maria: \# Wer war es?

Who was it?

or Indifference

Modals 5

(7) Hans: Wen soll ich einladen?

Who shall I invite?

Maria: Irgendjemand / \# Jemand.

Indifference

Somebody or other. Somebody.

For reasons of space, we will primarily discuss the non-epistemic effects of irgendein in this paper. Our analysis should carry over to the epistemic cases, however, assuming that declarative sentences have assertoric operators that might trigger implicatures relating to the common ground of the conversation. When experimenting with the properties of irgendein, we have to be aware of the epistemic interpretation, however. Sentence (8) is ambiguous, for example:

(8) Mary musste irgendeinen Mann heiraten.

Mary had-to irgend-one man marry.

(a) There was some man Mary had to marry, the speaker doesn't know or care who it was.

4. Examples (5) and (6) are due to Haspelmath (1997).

5 Example (7) is from the Akademiegrammatik 1981, p. $667 \mathrm{f}$. 
(b) Mary had to marry a man, any man was a permitted marriage option for her.

As illustrated in (5) to (8), irgendein indefinites have a special relation with modals and the options they provide, be they epistemic, deontic, or what not. The special link with modality is a well-known property of free choice indefinites and plays a crucial role in the analyses of free choice indefinites proposed in Dayal 1998, Giannakidou 2001, and Saebø 2001. The connection with modality provides the key to an understanding of the free choice effect. However, existing accounts of the free choice effect struggle with the traditional assumption that modals select propositions, hence can't really 'see' a free choice indefinite buried somewhere in their scope. There is currently no compositional account of the link between free choice indefinites and modals, nor an explanation why there should be such a link. Our analysis of the free choice effect is based on the idea that free choice indefinites - like all indeterminate phrases - create Hamblin sets, hence alternatives. Those alternatives keep expanding until they meet an operator that can make use of them. In this way, a local link between an indefinite and a modal can be established. The alternatives created by the indefinite can then be 'distributed over' the set of accessible worlds, as Dayal and Giannakidou envisaged. On our account, the alternatives to be distributed grow into propositions, and are not individuals any longer. This is what makes a compositional semantics for free choice indefinites possible.

\section{What IS the relation with Modality?}

To see how the alternatives created by an indefinite can relate to the accessible worlds introduced by a modal, let us look at two scenarios and how to 
describe them. First scenario: Mary has to marry a doctor, and any doctor is a permitted option. Her deontic options look as follows, then:

Dr. Curtz

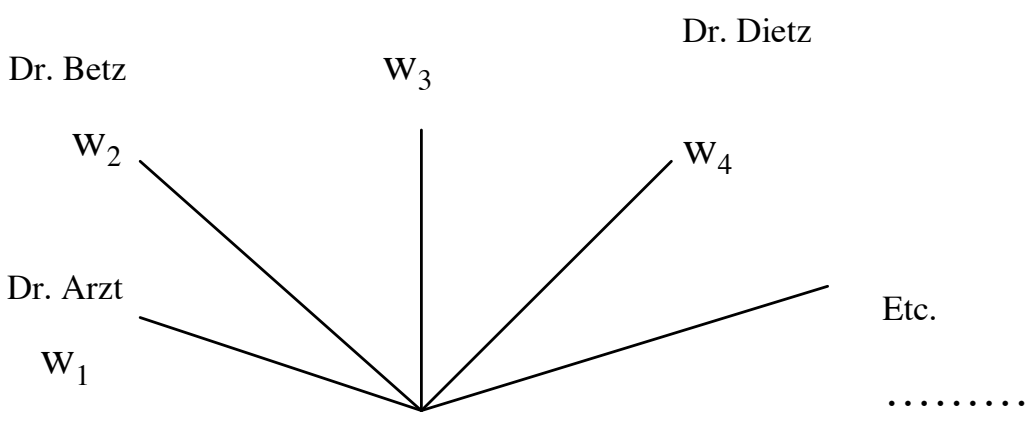

Sentence (9) can felicitously describe such a situation.

(9) Mary muss irgendeinen Arzt heiraten.

Mary has to irgend-a doctor marry

'Mary has to marry a doctor, any doctor is a permitted option.'

Second scenario: Mary has to marry one of two doctors, Dr. Heintz or Dr. Dietz, and those are the only permitted options for her. This time, her deontic options look as follows:

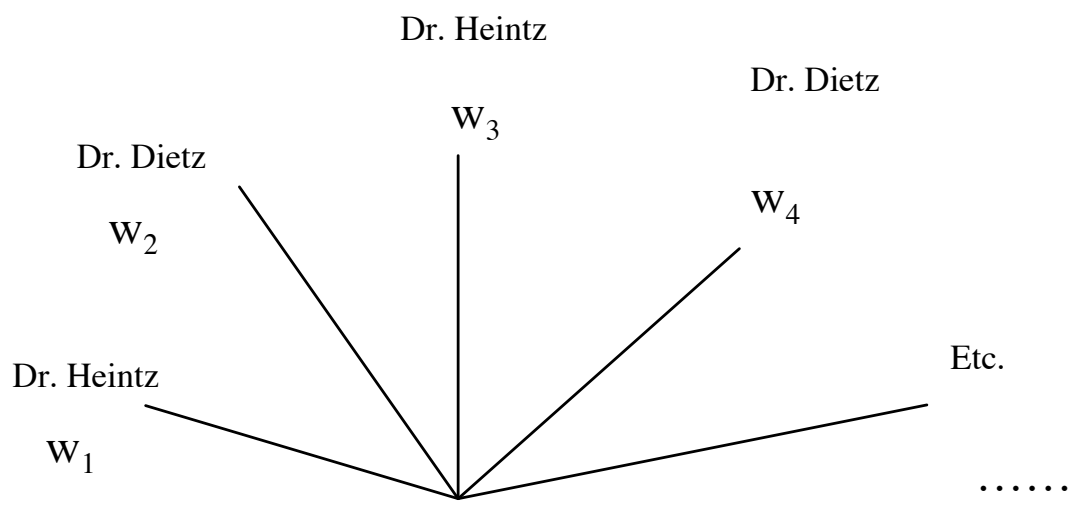

(9) cannot felicitously describe such a situation, so long as our universe of discourse contains more than two men. Using (10) would be fine in both cases. 
(10) Mary muss einen Arzt heiraten.

Mary has to a doctor marry

'Mary has to marry a doctor'

The examples illustrate what it means for the propositional alternatives created by a free choice indefinite to be 'distributed over' the accessible worlds introduced by a modal. Irgendein, unlike simple ein, induces maximal widening of the domain, as Kadmon and Landman have observed for English any. In our example, there has to be a propositional alternative 'Mary marry $\mathrm{x}$ ' for each and every man $\mathrm{x}$. The meaning of the modal must requires that in every accessible world, one of those alternatives be true. All by itself, however, this requirement is still compatible with Mary marrying the same man in every accessible world. To get the free choice effect, we need the additional requirement that there be an accessible world for every alternative created by irgendein. The challenge we are facing is to explain where that second requirement, the distribution requirement, should come from. The following section will show that the distribution requirement is not part of the meaning of the modal. If it was, it would have the status of a logical implication. We'll argue that it is a conversational implicature. It completely, but predictably, disappears in certain environments.

\section{The distribution requirement is a conversational implicature}

That the distribution requirement is not a logical implication is suggested by the fact that it can be cancelled. 
(11) Du musst irgendeinen Arzt heiraten, und das darf niemand anders You must irgend-one doctor marry and that may nobody else

sein als Dr. Heintz.

be than Dr. Heintz

'You must marry some doctor or other, and it can't be anybody but Dr. Heintz.'

A second and more reliable indication that the distribution requirement is a conversational implicature is the fact that it disappears in downward entailing contexts, (Gazdar 1979, Horn 1989, Chierchia 2001). You need a special focus particle or emphatic stress (as in (14) ) to retain it.

(12) Niemand musste irgendjemand einladen. Nobody had to irgend-one invite 'Nobody had to invite anybody'.

(13) Ich bezweifle, dass sie je irgendjemand einladen durfte. I doubt that she ever irgend-one invite could 'I doubt that she was ever allowed to invite anybody.'

(14) Sie darf nie einfach nur IRGENDjemand einladen. She may never just only irgend-one invite. 'She is never allowed to invite just ANYbody.'

If the distribution requirement was part of the meaning of must, sentence (12), for example, could be true in a situation where people had to invite a particular person, hence weren't given any options. This is clearly not so. We should now be able to derive the distribution requirement pragmatically in interaction with a plausible semantics for irgendein and the modals. We'll present the semantics of irgendein and the modals must and can in the following section, and will then 
illustrate in section 8 how the distribution requirement can be derived via Gricean reasoning.

\section{Deriving the special relation with modality. A Hamblin semantics.}

For comparison, we will start with the semantics of simple indefinites: For all possible worlds $\mathrm{w}$ and variable assignments $\mathrm{g}$ we have:

$\mathrm{g}(\mathbf{D}) \square \mathrm{D} \quad$ ( $\mathrm{D}$ is the set of possible individuals)

$\left[\left[\operatorname{ein}_{\mathrm{D}} \text { Mann }\right]\right]^{\mathrm{w}, \mathrm{g}}=\{\mathrm{x}: \mathrm{x}$ is a man in $\mathrm{w} \& \mathrm{x} \square \mathrm{g}(\mathbf{D})\}$

DPs headed by ein denote subsets of their common noun set. Ein Mann, then, denotes a subset of the set of men. Which subset depends on the domain variable D, whose value might be provided by the context. In the limiting case, ein Mann might denote a singleton with a single man in it. We would have a singleton indefinite, then, as Roger Schwarzschild has called them (Schwarzschild 2000). As for irgendein, the main effect of irgend- is to widen the domain. This is the signature of a free choice indefinite. Following Chierchia 2001, the semantics of widening looks as follows:

For $[[\square]]^{\mathrm{w}, \mathrm{g}} \square \mathrm{D}_{\mathrm{e}}$ :

$[[\text { irgend- } \square]]^{\mathrm{w}, \mathrm{g}} \quad=\left\{\mathrm{x}: \square \mathrm{g}^{\prime}\left[\mathrm{x} \square[[\square]]^{\mathrm{w}, \mathrm{g}^{\prime}}\right]\right\}$

$\left[\left[\right.\right.$ irgend- [ein ${ }_{\mathrm{D}}$ Mann ] ] ] ${ }^{\mathrm{w}, \mathrm{g}}=\left\{\mathrm{x}: \square \mathrm{g}^{\prime}\left[\mathrm{x}\right.\right.$ is a man in $\left.\left.\mathrm{w} \& \mathrm{x} \square \mathrm{g}^{\prime}(\mathbf{D})\right]\right\}$

$=\{\mathrm{x}: \mathrm{x}$ is a man in $\mathrm{w}\}$

In contrast to ein Mann, irgendein Mann has to denote the set of all men. It cannot denote a proper subset of the men. As long as there is more than one man, then, irgendein Mann cannot be a singleton indefinite. As for the modals, it is 
tempting to take them to be operators over sets of propositional alternatives. In this way, they can be sensitive to the alternatives introduced by indeterminate pronouns in their scope:

Modal $[\ldots \ldots \ldots \ldots$ Irgendein NP $\quad \ldots \ldots \ldots \ldots . .$.

Expanding Alternatives

Another possibility would be to let modals operate on singleton sets of propositions, but assume that their scope is immediately closed by the operator $\square$. What we have described as an interaction between an indefinite and a modal, would then technically be an interaction between a modal $+\square$ combination and an indefinite. We'll see shortly that this second possibility is correct, but we'll carry on with the first possibility for illustration. A possibility modal, then, says that some proposition in the alternative set it operates over is true in some accessible world. A necessity modal requires that for every accessible world, there be some proposition in the alternative set that is true in it. The distribution requirement is the same in both cases: For every proposition in the alternative set, there has to be an accessible world in which it is true.

Possibility Modals: Meaning

For $[[\square]]^{\mathrm{w}, \mathrm{g}} \square \mathrm{D}_{<\mathrm{st}>}:[[\text { kann } \square]]^{\mathrm{w}, \mathrm{g}}=$

$\left\{\square w^{\prime} \cdot \square w^{\prime \prime}\left[w^{\prime \prime}\right.\right.$ is accessible from w' \& $\left.\left.\square p\left[p \square[[\square]]^{w^{\prime}, \mathrm{g}} \& \mathrm{p}\left(\mathrm{w}^{\prime \prime}\right)=1\right]\right]\right\}$

Necessity modals: Meaning

For $[[\square]]^{\mathrm{w}, \mathrm{g}} \square \mathrm{D}_{<\mathrm{st}>}:[[\text { muss } \square]]^{\mathrm{w}, \mathrm{g}}=$

$\left\{\square \mathrm{w}^{\prime} \cdot \square \mathrm{w} \mathrm{w}^{\prime}\left[\mathrm{w}{ }^{\prime \prime}\right.\right.$ is accessible from w' $\left.\left.\square \mathrm{p}\left[\mathrm{p} \square[[\square]]^{\mathrm{w}, \mathrm{g}} \& \mathrm{p}\left(\mathrm{w},{ }^{\prime}\right)=1\right]\right]\right\}$ 
Distribution Requirement (to be derived as an implicature, see below)

$\left\{\square \mathrm{w}^{\prime} \cdot \square \mathrm{p}\left[\mathrm{p} \square[[\square]]^{\mathrm{w}, \mathrm{g}} \square \square \mathrm{w}{ }^{\prime \prime}\left[\mathrm{w}^{\prime \prime}\right.\right.\right.$ is accessible from w'\& $\left.\left.\left.\mathrm{p}\left(\mathrm{w},{ }^{\prime}\right)=1\right]\right]\right\}$

The $\mathrm{t}$ (ruth-conditional)-content of the modals is thus standard and weak. The distribution requirement distributes the propositional alternatives generated by irgendein over the accessible worlds. The task ahead is to derive that requirement.

\section{The pragmatic derivation of free choice implicatures}

Irgendein, like any free choice item, induces maximal widening of the set of alternatives as part of its lexical meaning. An important insight of Kadmon \& Landman 1993 is that this widening should be for a reason. Since they were dealing with any, the obvious reason in their case was strengthening of the statement made. This will not do for us. With a 'pure' existential, widening usually makes your statement weaker. That there is some man in the whole world, for example, is a weaker thing to say than there is some man in this room. Strengthening cannot always be the purpose of domain widening, then. Sometimes, weakening is what is called for to avoid a false claim. With existentials, then, widening might help avoid a false claim. To those two possible reasons for domain widening we propose to add a third, that's intimately tied to any semantics based on alternatives: Avoidance of false exhaustivity inferences. Exhaustivity inferences have been discussed for the semantics of questions by Groenendijk \& Stokhof 1984, and for lists of possibilities by T. E. Zimmermann 2000. Zimmermann's work is particularly relevant, since it concerns the interaction between modals and or, which is likely to parallel the interaction between modals and indefinites. Here is a simple example of an exhaustivity inference: 
(15) 2 books are under discussion. An algebra book and a biology book. I say to you: You can borrow the algebra book.

Exhaustivity inference: You cannot borrow the biology book.

My mentioning of the algebra book might trigger an inference about the biology book, given that it was among the alternatives under discussion. The inference is that I don't want you to borrow the biology book. It's an exhaustivity inference based on the assumption that my mentioning one book option for you exhausted your options. The reason why exhaustivity inferences are expected to play a major role in a semantics based on alternatives is that if alternatives are created in the semantics, they have to be reckoned with no matter what. They can't be 'contextualized away'. Let us assume, then, that domain widening might serve any of the following reasons: (a) strengthening of the claim, (b) avoiding a false claim, (c) avoiding a false exhaustivity inference ${ }^{6}$. We can now derive the distribution implicatures triggered by irgendein via Gricean reasoning. Here is the strategy: We are trying to reconstruct why the speaker chose to widen the domain by using a free choice existential like irgendein. We are assuming that widening could in principle serve any one of the 3 reasons we have mentioned. If we can figure out which one of those reasons led to the widening of the domain, we can use what we found to strengthen the statement that was actually made. As we will see, it can also happen that the reason for the widening is already logically implied by the claim made. In that case, the claim cannot be strengthened by figuring out why it was made, and no implicature is generated. This is when we say that the implicature is "cancelled." For ease of exposition, we'll illustrate the pragmatic 
derivation of the distribution implicature for the case of just two alternatives, and we will work through three representative examples in some detail.

Possibility

(16) $\mathrm{Du}$ kannst dir irgendeins von diesen beiden Büchern leihen. You can you(dat.) irgend-one of those two books borrow. 'You can borrow one of those two books, it doesn't matter which.'
Alternative set chosen:
Can $\{\mathrm{A}, \mathrm{B}\}$.
T(ruth-conditional) content:
$\mathrm{P}\left(\begin{array}{ll}\mathrm{A} & \mathrm{B}\end{array}\right)$

Figuring out the implicature

She picked the widest set of alternatives, $\{A, B\}$. Why didn't she pick $\{A\}$, which would have led to a stronger claim? Suppose $\mathrm{P}(\mathrm{A})$ is false. Then she should have made the stronger claim $\mathrm{P}(\mathrm{B})$. Why didn't she? It couldn't be because the exhaustivity inference $\neg \mathrm{P}(\mathrm{A})$ is false. Assume, then, that $\mathrm{P}(\mathrm{A})$ is true. The reason why she nevertheless made the weaker claim $\mathrm{P}\left(\begin{array}{ll}\mathrm{A} & \mathrm{B}\end{array}\right)$ would now have to be that the exhaustivity inference $\neg \mathrm{P}(\mathrm{B})$ is false. We infer $\mathrm{P}(\mathrm{A}) \square \mathrm{P}(\mathrm{B})$. Parallel reasoning for why she didn't pick $\{\mathrm{B}\}$ leads to $\mathrm{P}(\mathrm{B}) \square \mathrm{P}(\mathrm{A})$.

Computing the total meaning of (16)

$\mathrm{P}(\mathrm{A} \quad \mathrm{B})$

T-content of claim

$\mathrm{P}(\mathrm{A}) \square \mathrm{P}(\mathrm{B})$

Implicature

$\mathrm{P}(\mathrm{A}) \& \mathrm{P}(\mathrm{B})$

Total meaning

\footnotetext{
6. There is some discussion in Groenendijk \& Stokhof's and Zimmermann's work concerning the status of exhaustivity inferences. Staying agnostic with respect to this issue, we are using the neutral term "inference".
} 
Necessity

(17) Du musst dir irgendeins von diesen beiden Büchern leihen. You must you(dat.) irgend-one of those two books borrow. 'You must borrow one of those two books, it doesn't matter which.'

Alternative set chosen:

T(ruth-conditional) content:
Must $\{\mathrm{A}, \mathrm{B}\}$.

$\mathrm{N}(\mathrm{A} \quad \mathrm{B})$

Figuring out the implicature

She picked the widest set of alternatives, $\{A, B\}$. Why didn't she pick $\{A\}$, which would have led to a stronger claim? It might be that $\mathrm{N}(\mathrm{A})$ is false. Or else, it might be that $\mathrm{N}(\mathrm{A})$ is true, but its exhaustivity inference $\neg \mathrm{N}(\mathrm{B})$ is false. We infer $\mathrm{N}(\mathrm{A}) \square \mathrm{N}(\mathrm{B})$. The same kind of reasoning can be given for why she didn't pick $\{B\}$, and we infer $N(B) \square \mathrm{N}(\mathrm{A})$.

Computing the total meaning of (17)

$\mathrm{N}\left(\begin{array}{ll}\mathrm{A} & \mathrm{B}\end{array}\right)$

$\mathrm{N}(\mathrm{A}) \square \mathrm{N}(\mathrm{B})$

$\mathrm{N}(\mathrm{A} \quad \mathrm{B}) \&(\mathrm{~N}(\mathrm{~A}) \square \mathrm{N}(\mathrm{B}))$

$\mathrm{N}(\mathrm{A} \quad \mathrm{B}) \& \mathrm{P}(\mathrm{A}) \& \mathrm{P}(\mathrm{B})$
T-content of claim

Implicature

Total meaning

Implication of total meaning 


\section{Negated Possibility ${ }^{7}$}

(18) Du kannst dir You can you(dat.) in no

Büchern leihen.

books borrow.

'In no case can you borrow any one of those two books'.
Alternative set chosen:
$\square$ Can $\{A, B\}$.
T(ruth-conditional) content:
$\square \mathrm{P}(\mathrm{A} \quad \mathrm{B})$

Failed attempt to derive an implicature

Why didn't she pick the smaller set of alternatives $\{A\}$ ? Avoiding a false claim?

This can't be, since $\square \mathrm{P}(\mathrm{A})$ follows from what she said, so she can't think it is false. Could widening have served the purpose of strengthening? Yes, but we know that without making any further factual assumptions. Could widening have served the purpose of avoiding a false exhaustivity inference? Yes, but, again, we know that without making any further factual assumptions. What she said implies that the exhaustivity inference of $\square \mathrm{P}(\mathrm{A})$ is false. The same kind of reasoning applies to $\{B\}$, the other smaller alternative set.

\section{Computing the total meaning of (18)}

Since there is no implicature, the total meaning is the same as the T-content of the claim: $\square \mathrm{P}\left(\begin{array}{ll}\mathrm{A} & \mathrm{B}\end{array}\right)$. Reconstructing why the widening took place doesn't yield any statements that are not already implied by what she said. The implicature is "cancelled". 
We have seen that a Japanese-style Hamblin semantics can account for two properties of free choice indefinites. It explains how indefinites can interact with far-away modals in a compositional way, and also why the distribution requirement that is responsible for the free choice effect is in force in some environments, but not others. A Japanese-style alternative semantics was essential for those explanations. Expanding Hamblin alternatives can bridge the distance between indefinites and their operators, and exhaustivity inferences that come with those alternatives play an important role in producing the free choice effect. A semantics based on alternatives also establishes an immediate connection to existing accounts of negative polarity items, in particular English any. A number of authors, including Krifka 1994, 1995, Lee and Horn 1994, and Lahiri 1998 have argued that negative polarity items of the any NP type are best understood as consisting of an indefinite NP and an affective component comparable to English even. Krifka 1994, 1995 develops this idea within an alternative semantics where negative polarity items introduce individual alternatives that can expand to propositional alternatives via the same semantic mechanism used in a Hamblin semantics. Krifka is assuming a multidimensional semantics, a difference that is irrelevant for our present concerns. What is important is that the long-distance relation between the even-part and the indefinite part of any NPs is established via expanding alternatives, just as in our account of the free choice effect. Moreover, the meaning contribution of the even part essentially relies on alternatives. While there are minor divergences in detail, it is exciting to see how different courses of inquiry all converge on the same semantic architecture for indeterminate phrases.

7 In (18), auf keinen Fall was chosen, since irgendein can't be in the scope of inflectional negation. 
In the remaining sections of this paper, we will demonstrate that if we look at the behavior of irgendein under the new perspective we have gained, we'll find more Japanese behavior. We'll also find some differences that have to be explained.

\section{Long distance relations and selectivity}

If a Japanese semantics is right for irgendein, we should find long distance relations between possibly multiple occurrences of irgendein and 'their' modal. We do. (19) has meanings (a) and (b).

(19) Mary muss irgendeinen Mann heiraten, der irgendwo Mary must irgend-one man marry who irgend-where in Bayern wohnt. in Bavaria lives.

a. There is a man who lives somewhere in Bavaria who Mary has to marry, (the speaker doesn't know or care who it is and where he lives in Bavaria.)

b. Mary has to marry a man who lives somewhere in Bavaria, (any man who lives anywhere in Bavaria is a permitted marriage option for Mary).

On both readings, irgendwo associates with a modal across a relative clause boundary. Interestingly, reading (c) is absent (for reasons we'll discuss shortly):

c. * There is a place in Bavaria (the speaker doesn't know or care what place it is) and Mary must marry a man from that place, (any man from there is a permitted choice for Mary).

In contrast to its Japanese cousins irgendein is selective. It cannot associate with [०], for example ([ए] presumably contributes to the generic reading):

(20) Irgendeins von diesen Kindern kann sprechen. Irgend-one of these children can talk. 
a. 'One of those children can talk' (the speaker doesn't know or care which one it is).

b. 'One of those children is allowed to talk' (any one is a permissible option).

c. * Any one of those children can talk (in the sense of 'any one of those children has the ability to talk.')

Irgendein NPs can't associate with [Neg] either, nor with [Q] :

* Ich hab' nicht irgendwas gelesen. ${ }^{8}$

I have not irgend-what read

'I didn't read anything.'

(22) Der Lehrer hat gefragt, $\underline{o b}$ Hans irgendein Buch gelesen hat. The teacher has asked whether Hans irgend-one book read has. 'The teacher asked whether Hans read any book.'

Impossible reading

The teacher asked whether $\{$ Hans read book a, Hans read book b, Hans read book $\mathrm{c}, \ldots . .$. etc. for all books in the universe of discourse $\}$

It seems that the only operator irgendein indefinites can associate with is [D]. This is the reason why, as alluded to earlier, we do not want irgendein indefinites to associate directly with modals. Assuming a traditional semantics for modals plus [ [] -closure of their scope will deliver the right result without any further changes. [ [] -closure of the scope of certain operators has been argued for in Heim 1982, and is a common assumption in Discourse Representation Theory. It is

8. If irgend is stressed, you get the reading 'I didn't read just ANYthing.' 
needed in other cases we have discussed. Compare (21) with sentences (12) and (18) above:

(12) Niemand musste irgendjemand einladen. Nobody had to irgend-one invite 'Nobody had to invite anybody'.

(18) Du kannst dir auf keinen Fall irgendeins von diesen beiden You can you(dat.) in no case irgend-one of those two

Büchern leihen. books borrow. 'In no case can you borrow any one of those two books'.

(21) is ungrammatical because it has nicht, signalizing the presence of inflectional negation. Irgendein is entirely acceptable in the scope of niemand ('no body'), auf keinen Fall ('in no case'), or nie ('never'), showing that German makes a distinction between inflectional negation and negative quantifiers. Assuming that inflectional negation is [Neg], but negative quantifiers close their scope with [D] accounts for the difference.

Why is it that irgendein and many of its Indo-European relatives can be so selective? A property we can't overlook is that they look selective. Existential irgendein, does not resemble its interrogative or negative siblings wer and niemand. The pronouns in the Latvian paradigm we introduced at the beginning of this paper show a common core, but there are clearly marked differences also. We mentioned already that the kaut- series has existentials, and that the ne-series appears under the direct scope of negation. The jeb-series occurs in indirect negation contexts, in comparatives, and with a free choice interpretation. In 
contrast, the Japanese indeterminate pronouns do not change shape when they associate with different kinds of operators. They always look the same.

Following much work in the minimalist tradition, suppose that selective indeterminate phrases like the German irgendein series or the Latvian kaut, ne, or jeb series have uninterpretable, but pronounceable features $[\square],[\square],[\mathrm{Neg}]$, or $[\mathrm{Q}]$. It's those features that give them their distinctive look. The interpretable versions of those features would be the operators $[\square],[\square],[\mathrm{Neg}],[\mathrm{Q}]$, most likely carried by inflectional categories like 'episodic' or 'generic' aspect, inflectional negation, and wh-complementizers. The uninterpretable features would have to be checked against their interpretable counterparts, and this should trigger movement of either the features alone or the whole DPs, as suggested in Chomsky 1995 and Pesetsky 2000. Pesetsky's work is very relevant, since he argues that feature movement is not merely the proper way of analyzing covert movement. If Pesetsky is right, we expect three types of movements in the realm of quantification: Overt scope shifts, covert scope shifts, and feature movement. Both overt and covert scope shifts are amply attested in German. The syntactic expression of the relation between an indeterminate phrase and its operator could now be feature movement.

Assuming, as is natural, that feature movement is stopped by non-matching operators, the ungrammaticality of (21) and the Beck Effects (Beck 1996) in (23) fall out. 
(23) a. *Was hat sie nicht WEM gezeigt?

What has she not to-whom shown

'What didn't she show to whom?'

b. *Was hat sie nie WEM gezeigt?

What has she never to-whom shown

'What didn't she show to whom?'

c. *Was hat niemand WEM gezeigt?

What has nobody to-whom shown

'What did nobody show to whom?'

d. * Was hat fast jeder WEM gezeigt?

What has almost everybody to-whom shown

'What did almost everybody show to whom?'

e. * Was hat (irgend) jemand WEM gezeigt?

What has somebody to-whom shown

'What did somebody show to whom?'

f. Was hat der Hans WEM gezeigt?

What has the Hans to-whom shown

'What did Hans show to whom?'

g. Was hat sie damals WEM gezeigt?

What has she then whom shown?

'What did she show whom at the time?'

In (21), uninterpretable [ $[$ ] bumps into interpretable [Neg]. In the examples of (23), movement of uninterpretable [Q] from the wh-phrase in situ is blocked by intervening operators. In 23(a), the culprit is [Neg]. For (irgend)jemand in 23(e) to be acceptable it has to be in the scope of interpretable [ [] . But then WEM would be in the scope of that $[\square]$ as well, and its [Q] feature would run against $[\square]$. 
Assuming that niemand ('nobody'), nie ('never'), and fast jeder ('almost everyone') close their scope with $[\square]$, that $[\square]$ will block the [Q] feature of WEM as well. A covert scope shift seems to be ruled out, presumably because the blocked item could shift over its intervener overtly in this configuration via object shift or scrambling:

(24) a. Was hat sie WEM nicht gezeigt?

What has she to-whom not shown

'What didn't she show to whom?'

b. Was hat sie WEM nie gezeigt?

What has she to-whom never shown

'What didn't she show to whom?'

c. Was hat WEM niemand gezeigt?

What has to-whom nobody shown

'What did nobody show to whom?'

d. Was hat WEM fast jeder gezeigt?

What has to-whom almost everybody shown

'What did almost everybody show to whom?'

e. Was hat WEM (irgend)jemand gezeigt?

What has to-whom somebody shown

'What did somebody show to whom?'

There are intriguing interactions between scope shifts and feature movement. The possibility of overt and covert scope shifts produces three possible readings for (25), for example:

(25) Hans will, dass Mary irgendeinen Mann heiraten darf. Hans wants that Mary irgend-one man marry may 
(a) There is a man who Hans wants Mary to be allowed to marry, (the speaker doesn't know or care who it is).

(b) Hans wants there to be a man who Mary is allowed to marry, (any man would be fine with him).

(c) Hans wants Mary to be allowed to marry a man (she should be allowed to pick any man).

All scope shifts seem to respect islands and this is why the reading 19(c) above is ruled out. (22) from above illustrates how the components of our analysis work together to produce rather subtle semantic facts. (22) has a single reading. Moreover, there is a 'feeling' that there is 'no free choice effect'.

(22) Der Lehrer hat gefragt, ob Hans irgendein Buch gelesen hat. The teacher has asked whether Hans irgend-one book read has 'The teacher asked whether Hans read any book.'

(i) $\sqrt{ }$ irgendein stays within the domain of $\square$ within the ob-clause.

(ii) * irgendein scopes over $\square$, but stays within the ob-clause.

(iii) *irgendein scopes out of the ob-clause.

(iv) * The alternatives created by irgendein expand beyond $\square$.

On our account, (ii) produces a feature clash with [Q], (iii) violates scope constraints, and (iv) can't happen because the expanding alternatives are caught by ๑. Our derivation of the free choice effect in section 8 was based on the assumption that domain widening has to be for a reason. The reasons we came up with were reasons applying to assertions. They can hardly be expected to carry over to questions. Questions do not make claims. What purpose might domain 
widening serve in questions, then? Does 'strength' play a role in any way? ${ }^{9}$ (22) ascribes a slight bias to the teacher's question. The bias could go either way. The teacher might be kind and try to elicit a positive answer. Domain widening can bring in marginal reading materials, comic books and computer manuals that might establish Hans as a reader. By asking the question the way he did, the teacher made sure that even the weakest positive answer would be considered. But the teacher might also be evil, knowing very well that Hans hasn't read anything at all. Anticipating a negative answer, he hopes that widening the domain will increase the public embarrassment for Hans. If Hans hasn't even read comic books or computer manuals, he is hopeless. In this case, the teacher was shooting for the strongest negative answer. That's the kind of things that widening could do in questions. Given the way we derived the free choice implicature earlier, we expect it to be "cancelled" in questions. Of course, "cancelled" is the wrong word to use.

In this section, we have focused on a salient difference between 'typical' IndoEuropean indeterminate pronoun paradigms and the Japanese series, their visible selectivity. We suggested that this difference might be represented by the presence or absence of pronounceable, but uninterpretable features corresponding to the interpretable operators $[\square],[\square],[\mathrm{Neg}],[\mathrm{Q}]$. If uninterpretable features carried by DPs have to be checked against interpretable counterparts carried by inflectional heads, we expect that Indo-European style indeterminate phrases might be able to scope, and we might also find the signs of feature movement. Overt or non-overt scoping is a well-investigated phenomenon, maybe the most studied phenomenon in the area of quantification. Overt scoping can be seen or heard, and covert scoping can be easily identified, too, because it affects semantic interpretation.

\footnotetext{
9. See Krifka 1994, 1995 for an assessment in the same spirit as the following rather sketchy remarks.
} 
Feature movement is harder to detect, as documented in Pesetsky 2000. Feature movement is likely to be at work when an indeterminate phrase is stuck in the scope of a non-matching operator it can't covertly skip over for some reason, as in examples (21) and (23). It produces Beck effects. Negative concord and certain cases that are traditionally classified as polarity sensitivity may turn out to be special cases of the same effect. In all of those cases, ungrammaticality is produced when a DP finds itself in the scope of an 'incompatible' operator. If our speculations are on the right track, we might eventually understand how complicated syntactic behavior may be triggered by a rather insubstantial difference affecting lexical items.

There are many consequences to follow up on. One would be to explore whether even within a single language, morphological differences between indeterminate

pronouns lead to the expected differences in syntactic behavior. After all, the kind of property that we held responsible for scoping and intervention effects is a morphological property of individual lexical items or paradigms, and not a parameter affecting a language as a whole. We hope to inspire more work on quantification in different languages by raising those questions at the end of our own investigation.

\section{Outlook}

In this paper we have pursued an approach to crosslinguistic variation that relies on what Matthewson (2001) has called "The No Variation Hypothesis". The hypothesis assumes that there is no crosslinguistic variation in semantics, "there are certain fundamental semantic structures or properties which all languages should share" (p. 156). Adopting this hypothesis as a research strategy has led us to an analysis of the German irgendein series that we could not have dreamed of 
otherwise. It has helped us solve a tough puzzle concerning the interaction of free choice indefinites and modals that establishes the expected parallel with or, for which Zimmermann 2000 has already proposed a semantics based on alternatives. Moreover, we were able to connect our results with existing work on negative polarity items. We also confirmed the view that indeterminate phrases do not have their own quantificational force, not even those, which like irgendein do not exhibit any quantificational variability. In this sense, we have preserved the pioneering insights of Hans Kamp, Irene Heim, and Taisuke Nishigauchi.

\section{References}

Autorenkollektiv (1981) Grundzüge einer deutschen Grammatik. Berlin (Akademieverlag).

Beck, S. (1996) Quantified Structures as Barriers for LF Movement. Natural Language Semantics 4(1), 1-56.

Chierchia, G. (2001) Scalar Implicatures, Polarity Phenomena, and the Syntax/Pragmatics Interface. Manuscript, U. of Milan, Bicocca.

Chomsky, N. (1995) The Minimalist Program. Cambridge MA: The MIT Press.

Dayal, V. (1998) Any as Inherently Modal. Linguistics \& Philosophy, 21(5), 433476.

Gazdar, G. (1979) Pragmatics. New York :Academic Press.

Giannakidou, A. (2001) The Meaning of Free Choice. Linguistics \& Philosophy $24,659-735$.

Groenendijk, J. \& M. Stokhof (1984) Studies on the Semantics of Questions and the Pragmatics of Answers. Universiteit van Amsterdam Ph.D. Dissertation. Hagstrom, P. A. (1998) Decomposing Questions. MIT Ph.D. Dissertation. 
Hamblin, C. L. (1973) Questions in Montague English. Foundations of Language $10,41-53$.

Haspelmath, M. (1997) Indefinite Pronouns. Oxford :Oxford University Press.

Heim, I. (1982): The Semantics of Definite and Indefinite Noun Phrases. UMass Ph.D. Dissertation.

Horn, L. R. (1989) A Natural History of Negation. Chicago: Chicago University Press.

Kadmon, N. \& F. Landman (1993) Any. Linguistics \& Philosophy 16, 353-422.

Kamp, H. (1984) A Theory of Truth and Semantic Representation. In J. Groenendijk, T. Janssen and M. Stokhof (eds.) Truth, Interpretation, and Information. Dordrecht: Foris, 1-41.

Krifka, M. (1994) Some Remarks on Polarity Items. In D. Zaefferer (ed.) Semantic Universals and Universal Semantics. Dordrecht: Foris, 150 -189. Krifka, M. (1995) The Semantics and Pragmatics of Polarity Items. Linguistic Analysis 25(3-4), 209-257.

Kuroda, S. - Y. (1965) Generative Grammatical Studies in The Japanese Language. MIT Ph.D. Dissertation.

Lahiri, U. (1998) Focus and Negative Polarity in Hindi. Natural Language Semantics 6(1), 57-123.

Lee, Y. S. \& L. Horn (1994) Any as Indefinite plus Even. Manuscript, Yale University.

Matthewson, L. (2001) Quantification and the Nature of Crosslinguistic Variation. Natural Language Semantics 9(2), 145 - 189.

Nishigauchi, T. (1986) Quantification in Syntax. UMass Ph.D. Dissertation. 
Nishigauchi, T. (1990) Quantification in the Theory of Grammar. Dordrecht:

Kluwer.

Ohno, Yutaka (1989) Mo. In E. Bach et al. (eds.), Papers on Quantification, NSF

Grant Report, Department of Linguistics, UMass, Amherst, GLSA 224-250 .

Pesetsky, D. (2000) Phrasal Movement and its Kin. Cambridge/Mass: The MIT Press.

Ramchand, G. C. (1997) Questions, Polarity, and Alternative Semantics.

Proceedings of NELS 27, GLSA Amherst, 383-396.

Saebø, K.J. (2001) The Semantics of Scandinavian Free Choice Items.

Linguistics and Philosophy 24, 737-787.

Schwarzschild, R. (2000): Singleton Indefinites. Manuscript, Rutgers University.

Shimoyama, J. (1999) Complex NPs and Wh-Quantifiers in Japanese.

Proceedings of NELS 29, GLSA Amherst, 355-385.

Shimoyama, J. (2001) Wh-Constructions in Japanese. UMass Ph.D. Dissertation.

Stechow, A. v. (1996) Against LF Pied-Piping. Natural Language Semantics 4(1), 57-110.

Zimmermann, T. E. (2000) Free Choice Disjunction and Epistemic Possibility. Natural Language Semantics 8, 255 -290. 